\title{
Changes in Soil Composition and Floral Coverage on a Glacial Foreland Chronosequence in Southern Iceland
}

\author{
Lawrence H. Tanner ${ }^{1}$, Ann E. Walker ${ }^{2}$, Morgan Nivison ${ }^{1}$, David L. Smith ${ }^{1}$ \\ ${ }^{1}$ Department of Biological Sciences, Le Moyne College, Syracuse, USA; ${ }^{2}$ Department of Earth \& Planetary Sciences, and Science \\ Alliance Center of Excellence, University of Tennessee, Knoxville, USA. \\ Email: tannerlh@lemoyne.edu
}

Received May $24^{\text {th }}, 2013$; revised June $24^{\text {th }}, 2013$; accepted July $2^{\text {nd }}, 2013$

Copyright (C) 2013 Lawrence H. Tanner et al. This is an open access article distributed under the Creative Commons Attribution License, which permits unrestricted use, distribution, and reproduction in any medium, provided the original work is properly cited.

\begin{abstract}
The land surface in front of the Skaftafellsjökull in southern Iceland, exposed by ice recession commencing about the start of the twentieth century, constitutes a foreland with a maximum age of about 100 years and a more distal outwash plain. The ages of different surfaces within this sequence are constrained by moraines of known or estimated ages. Across this chronosequence, we measured at various sites the extent of floral coverage of the surface, the soil carbon and nitrogen contents of the substrate and the soil $\mathrm{CO}_{2}$ flux rate. All measured parameters exhibit values increasing with distance from the ice front, which correlates approximately with age. The strongest correlations are seen between distance and the carbon and nitrogen concentrations of the soil. Marked horizonation of the soil is observed only on the oldest surfaces $(100+$ years).
\end{abstract}

Keywords: Skaftafellsjökull; Glacial Foreland; Chronosequence; Soil Carbon; Soil $\mathrm{CO}_{2}$ Flux

\section{Introduction}

Current concerns with climate change often focus on the carbon cycle, and more specifically, the various sources and sinks of carbon exchangeable on short (decadal) time scales. To this end, various studies have attempted to quantify the reservoirs and fluxes of carbon from both marine and continental reservoirs [1]. At a broad approximation, the biomass of primary producers stores $\mathrm{c}$. $600 \mathrm{Gt}$ of elemental carbon, somewhat less than the atmospheric reservoir of c. $760 \mathrm{Gt} \cdot \mathrm{C}$ and the estimated $1600 \mathrm{Gt} \cdot \mathrm{C}$ stored in soils and marine sediments [2]. The carbon in these reservoirs is rapidly exchangeable, with an annual flux of roughly $60 \mathrm{Gt}$ from the atmosphere to the biosphere (by photosynthesis) and approximately the same amount returned via respiration, decay and fermentation. Not surprisingly, given their immense bioproductivity, tropical ecosystems account for approximately $20 \%$ of the terrestrial organic carbon inventory, yet tundras also contain a not inconsiderable $8 \%$ of carbon stocks [3].

Accurate tracking of changes in the global carbon cycle will require a thorough understanding of the fluxes of carbon in all environments. Moreover, knowledge of how these fluxes will vary as a response to on-going and anticipated climate change is crucial to predicting changes in the size of these carbon reservoirs in the future. Currently, the ability of high-latitude lands to store excess atmospheric carbon is much lower than for tropical lands [4]. But warming at high latitudes, which likely will be of substantially greater magnitude than it will be in the tropics, is likely to modify the role of high latitude soils by changing both carbon storage, as bioproductivity increases, and carbon emission, as respiration is stimulated. As described in Callaghan and others [5], the response of arctic and subarctic ecosystems to climate change (e.g., changes in primary production) will depend on the response of microbial decomposers to temperature change and litter and water availability.

Glacial foreland chronosequences have long been considered optimal settings for the study of rates and processes of landscape modification through floral colonization and pedogenesis. For example, Messer [6] found that across glacial foreland chronosequences in southern Norway soil depth and organic content increased, and $\mathrm{pH}$ decreased with surface age. Significantly, this study found that although some soil property chronofunctions, e.g., cation exchange capacity, were variable with local climate conditions, others, such as $\mathrm{pH}$ and organic content, were not. Similarly, Matthews [7] well-documented the importance of organic processes in development and 
horizonation of the solum. However, the effects of climate warming in these environments are likely to be limited by nutrient availability. The importance of nutrient availability, specifically nitrogen fixation, was first investigated by Crittendon [8], who studied lichen colonization of glacial drift in southern Iceland. Later, Hodkinson and others [9] studied glacial foreland chronosequences on Svalbard and found that cyanobacterial colonization was important for raising nutrient status prior to vascular plant colonization. This study also found that vascular plant species richness increased for the first $\mathrm{c}$. 100 years, beyond which bryophytes increased in dominance.

This study examines the rates and interactions of the processes of floral colonization and soil formation in the sub-arctic environment of southern Iceland. The study was conducted on a chronosequence, i.e., a sediment surface on which the age of exposure is fairly well known. We conducted our study on the deposits of the Skaftafellsjökull that are currently being exposed by glacial recession.

\section{Study Location}

Vatnajökull, the largest ice cap in Iceland (and Europe), measures $8100 \mathrm{~km}^{2}$ (from Landsat in 1991) and is the source of nearly 30 individual outlet glaciers, most of which occupy valleys or broad, subglacial channels. For the most part, these glaciers reached their Little Ice Age maximum extent near the end of the nineteenth century, and have been in recession much of the time since. Comprehensive monitoring of the location of the ice front for most of these glaciers was initiated in the early 1930s, although earlier data exist for some glaciers. Data on the movements of these glaciers have been and continue to be collected by a combination of scientists and local residents. Measurements were made initially by tape measure and later by theodolite, and are archived by the Icelandic Glaciological Society. Tabulations of these data are published regularly in the journal Jökull. Most of these glaciers were in retreat through the 1930s and into the 1940 s, responding to a warming climate, but following cooling early in the latter half of the twentieth century, recession rates slowed through the 1950s and 1960s, and some glaciers re-advanced both in the early 1950s and in the late 1960s through 1970s. Consistent warming since the mid-1980s has led to retreat of almost all of these outlet glaciers over the last two decades.

Retreat of these glaciers over the past century or more has exposed foreland areas with varying topography. Most of the non-surging glaciers have left recessional moraines that can be dated reasonably accurately. The foreland of the Skaftafellsjökull was chosen for this study for two reasons: 1) the age of the land surface at various distances from the glacier terminus can be con- strained by the observations of ice recession and readvance described above; and 2) the location within Vatnajökull National Park (or Vatnajökulspjóðgarður, formerly Skaftafell National Park) has protected a portion of the land from grazing by large herbivores (sheep and reindeer) for several decades, allowing a natural progression of ecological succession. The most distal moraine of the Skaftafellsjökull that is clearly identifiable is located about $2 \mathrm{~km}$ from the current ice front and is approximately dated to the position of the terminus in 1904. A much more pronounced topography is formed by a set of nested moraines that may be associated with re-advance in the early 1950s [10]. A similar interval of re-advance occurred in the 1970s [10], and the most proximal set of moraines dates to the position of the glacial front as late as 1980. Between the moraines are flatter areas formed by alluvial outwash, incised channels and terraces. The ages of these inter-moraine surfaces are not as well constrained, other than by the moraines that form their boundaries, due to the potential of reactivation of the outwash channels over the course of many years. Therefore, the ages of the surfaces can best be characterized as the pre-1904 outwash plain, the 1904 moraine, the 19041950 outwash surface, the 1950s moraine, the 1950s1970 outwash surface, the 1980 moraine, and the post1980 surface. Thus, the outwash and foreland of the Skaftafellsjökull forms a chronosequence, more specifically a post-incisive chronosequence, sensu Vreeken [11] and Hugget [12], in which distance from the ice-front equates (approximately) to total age of the surface.

The study site is located at $64^{\circ} \mathrm{N}$ latitude, and despite the proximity to the Arctic Circle, is subject to a cool maritime climate. The annual mean temperature along the south coast is $4^{\circ} \mathrm{C}$ to $6^{\circ} \mathrm{C}$, with a winter (January) mean of near $0^{\circ} \mathrm{C}$, and a summer (July) mean of $10^{\circ} \mathrm{C}$, although air temperatures in proximity of the glacier are greatly variable and often significantly cooler. The land surface closest to the glacier is subject to katabatic winds of variable strength. Mean annual precipitation on this area of the south coast is approximately $1500 \mathrm{~mm}$.

\section{Methods}

We established 13 study sites between the current front of the glacier and the outwash plain distal to the position of the glacier at the start of the twentieth century, about 2 $\mathrm{km}$ from the present position of the terminus (Figure 1). At all of the sites, the substrate is stony and well drained.

Ten of these sites lie within an area that is fenced to prevent the entry of grazing animals, with the remaining three falling outside this boundary. At each site, we marked out a $50 \mathrm{~m}$ line oriented parallel to the glacial front and set sample locations every $10 \mathrm{~m}$ along this line.

The position of each site was recorded by GPS. At each of the five sample locations, vegetation (if any) was 


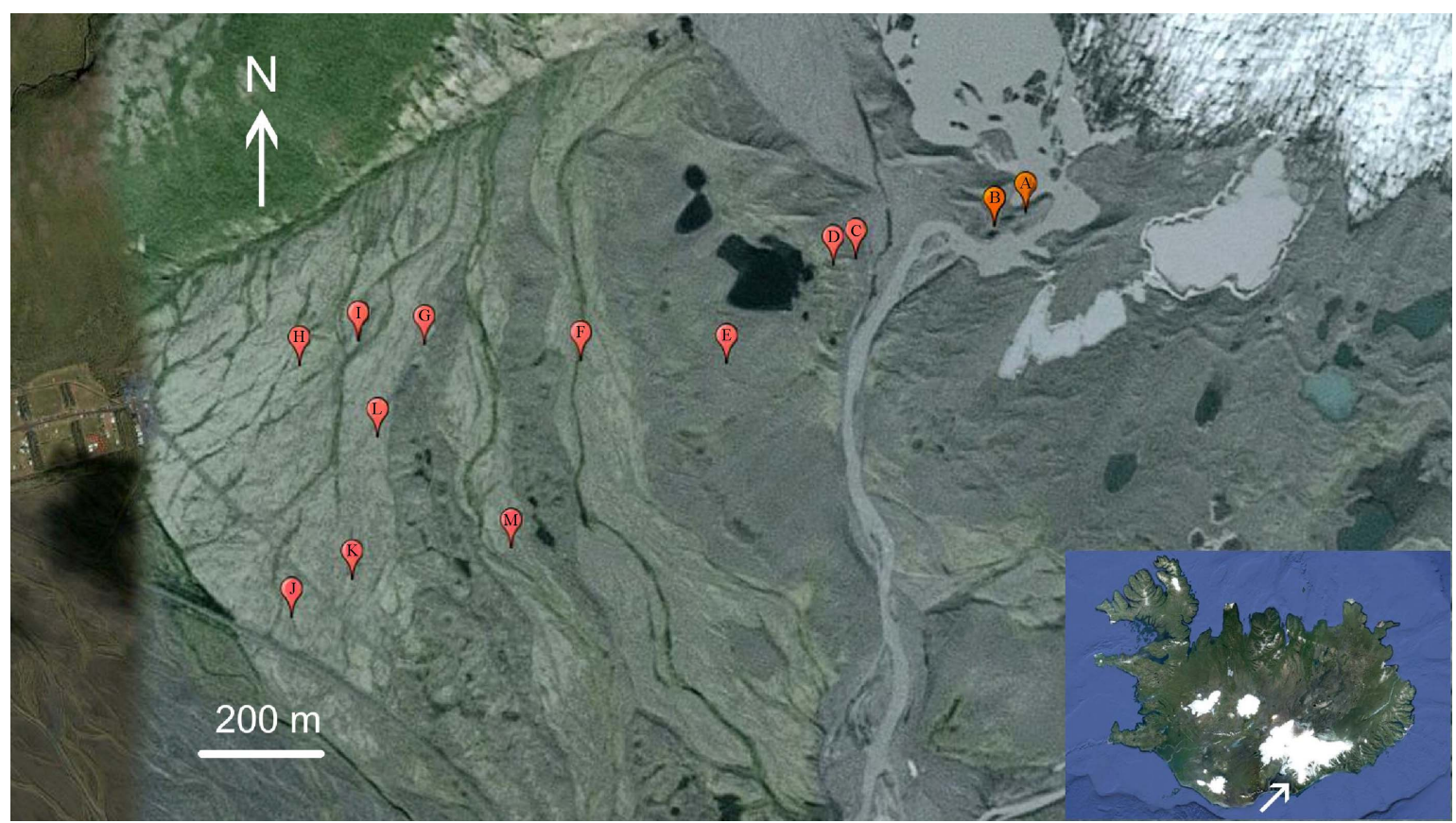

Figure 1. Aerial view of the foreland and outwash plain of the Skaftafellsjökull (ice visible to upper right). Sites B-D are in the ridges from the 1970s-1980s. The 1950s moraines occur on either side of Site M. The 1904 ridge is subdued, but is approximated by the position of Site I. Image adadpted from Google Earth ${ }^{\circledR}$, acquisition date 10/2012.

cleared and two $10 \mathrm{~cm}$ soil cores were drawn with a 2.5 $\mathrm{cm}$ diameter hand auger. The vegetation coverage was determined by visual estimation within a $0.25 \mathrm{~m}^{2}$ quadrat that was flipped four times to provide complete coverage for one square meter. The soil $\mathrm{CO}_{2}$ flux was measured at each sample location with a LI-COR LI- $8100 \mathrm{~A}^{\circledR}$ soil gas chamber system equipped with soil moisture and temperature probes. The collection chamber was set on a soil collar with $8 \mathrm{~cm}$ vertical offset. $\mathrm{CO}_{2}$ concentrations were measured continuously for 90 seconds following a 45 second purge cycle and the soil $\mathrm{CO}_{2}$ flux calculated from the regression line in units of $\mu \mathrm{mol} \mathrm{CO} / \mathrm{sec} / \mathrm{m}^{2}$.

Soil carbon and nitrogen content were measured from the soil cores. Each core was dried, homogenized, sieved with a $2 \mathrm{~mm}$ screen to remove larger rocks and root fragments, and the sub- $2 \mathrm{~mm}$ fraction pulverized. From each processed sample, 0.1 to $0.125 \mathrm{~g}$ was drawn for analysis with a Leco TruSpec $\mathrm{CN}^{\circledR}$ by combustion in a pure $\mathrm{O}_{2}$ atmosphere at $950^{\circ} \mathrm{C}$. The weight percent carbon and nitrogen were calculated from the composition of the evolved gases as measured by infrared and thermal conductivity cells, respectively.

In summary, the data collected at each of the 13 study sites included five soil $\mathrm{CO}_{2}$ flux measurements, 10 soil samples and 20 measurements of the floral coverage.

\section{Results}

The goal of this project was to characterize the processes and rates of change of the land surface of this chronose- quence following glacial retreat. Our investigation demonstrates a general trend of increasing plant cover, soil carbon, soil nitrogen and soil $\mathrm{CO}_{2}$ flux with increasing distance from the glacier, which approximates the age of the chronosequence surface, although with substantial variations among sample locations along each sample line (Table 1, Figure 2). Given that the range of ages of the land surfaces encompassed by this chronosequence spans approximately just over one century only, pedogenesis is more difficult to quantify. Distinctly visible horizonation is visible only on the oldest surfaces, as discussed below.

In addition to measuring the extent of vegetation cover at each sample location, we also made note of prominent plant species; a partial list of common species includes: red fescue grass (Festuca rubra), moss campion (Silene acaulis), woolly willow (Salix lanata), dwarf birch (Betula nana), downy birch (B. pubescens), crowberry (Empetrum nigrum), bearberry (Arctostaphylos uva-ursi), fleabane (Erigeron sp.), wild thyme (Thymus praecox), lady's bedstraw (Galium verum), heather (Calluna vulgaris), lady's mantle (Alchemilla sp.), purple saxifrage (Saxifraga oppositifolia), rough horsetail (Equisetum hiemale), biting stonecrop (Sedum acre), hairy stonecrop (S. villosum), various mosses, and foliose and crustose lichens.

Plant cover is sparse to nonexistent on the youngest surfaces in proximity to the glacier. Site A is located on gravelly till proximal to a proglacial lake, on a slope facing the glacier (Figure 3(A)) and therefore has an expo- 
Table 1. Summary data from all study sites. Cover $=\%$ surface area with vegetation (mean of 20 measurements); $\mathrm{C} \%$ and $\mathrm{N} \%$ represent mean of 10 samples each with standard deviation in parentheses; $\mathrm{Soil}_{\mathrm{CO}}$ flux represents mean of five measurements (reported in $\mu \mathrm{mol} / \mathrm{sec} / \mathrm{m}^{2}$ ).

\begin{tabular}{cccccccc}
\hline Site & Surface & Age & Distance $(\mathrm{m})$ & Cover\% & $\mathrm{C} \%(\sigma)$ & $\mathrm{N} \%(\sigma)$ & $\mathrm{Soil} \mathrm{CO}_{2}$ flux \\
\hline A & recent till & post-1980 & 236 & $<5$ & $0.075(0.006)$ & $0.027(0.033)$ & 0.07 \\
B & moraine & 1980 & 278 & 35 & $0.134(0.061)$ & $0.032(0.030)$ & 0.11 \\
C & moraine & $1970-1980$ & 564 & 65 & $0.19(0.11)$ & $0.163(0.186)$ & 1.97 \\
D & moraine & $1970-1980$ & 620 & 80 & $0.508(0.207)$ & $0.171(0.145)$ & 0.18 \\
E & terrace & $1950 \mathrm{~s}-1970$ & 970 & 60 & $0.108(0.067)$ & $0.091(0.038)$ & 0.4 \\
F & terrace & $1950 \mathrm{~s}-1970$ & 1209 & 75 & $0.181(0.046)$ & $0.18(0.047)$ & 1.82 \\
G & outwash & 1950 & 1405 & 65 & $0.645(0.374)$ & $0.165(0.029)$ & 2.08 \\
H & outwash & pre-1904 & 1672 & 90 & $0.614(0.296)$ & $0.12(0.056)$ & 0.38 \\
I & boulder moraine & 1904 & 1527 & 93 & $1.101(1.096)$ & $0.143(0.132)$ & 0.66 \\
J & outwash-grazed & pre-1904 & 1935 & 43 & $0.199(0.047)$ & $0.156(0.01)$ & 0.5 \\
K & moraine-grazed & 1904 & 1785 & 58 & $0.454(0.396)$ & $0.176(0.059)$ & 0.45 \\
L & outwash & $1904-1950$ & 1589 & 85 & $0.598(0.304)$ & $0.26(0.223)$ & 1.08 \\
M & terrace-grazed & $1950 \mathrm{~s}$ & 1485 & 38 & $0.463(0.074)$ & $0.142(0.089)$ & 0.77 \\
\hline
\end{tabular}

sure age of several decades at most. Vegetation is nearly absent with the exception mainly of widely separated tufts of grass (red fescue). The values of soil carbon, nitrogen and soil $\mathrm{CO}_{2}$ flux measured here are the lowest among all studied sites. Site B is directly in the lee of the most proximal ridge of the 1980 moraine. Floral cover is substantially higher, consisting mainly of moss, but also including abundant grass, wooly willow and crowberry (Figure 3(B)). Measurements of the carbon and nitrogen content of the soil are accordingly higher (Table 1). Sites $\mathrm{C}$ and $\mathrm{D}$ are also located on till within the nested moraines associated with the position of the ice front in the 1970s to 1980s (Figure 1). The floral cover is higher at these sites, and the measured soil carbon and nitrogen are successively higher at both of these sites. Soil $\mathrm{CO}_{2}$ flux at Site $\mathrm{C}$ was an order of magnitude higher than at Sites B or D.

Site E was situated on an elevated terrace located between the most recent moraine ridges and those formed in the early 1950s and the $1970 \mathrm{~s}$. The surface is covered by gravel to boulder-size clasts, although soil cores demonstrate a sandy-pebbly substrate beneath this coarse veneer, suggesting that the surface has been modified by deflation. Floral cover is lower and more discontinuous than at Sites C and D, consisting of patches of moss, willow and birch, and values of soil carbon, nitrogen and $\mathrm{CO}_{2}$ flux are all lower than at Sites $\mathrm{C}$ and D. Site F was situated on the terrace of a stream incised proxi higher on these alluvial gravels, dominated by moss, willow, northern crowberry and bearberry. Measurements of soil carbon, nitrogen and $\mathrm{CO}_{2}$ flux are all elevated with respect to Site F, and are similar to the values measured at Site C. Sites G and L are on the outwash flat immediately distal to the 1950 s boulder moraine. Although floral cover at Site $\mathrm{G}$ is lower than at Sites $\mathrm{L}$ and F, with moss providing the dominant coverage, soil carbon and soil $\mathrm{CO}_{2}$ flux are elevated with respect to both sites.

Sites $\mathrm{H}$ and I are distal to the glacier, with Site H situated on the outwash plain beyond the most distal moraine, an area of ridge and swale topography (Figure 3(D)). The oldest moraine is a subdued boulder ridge dated to 1904. Site I was located on the flat of this moraine. These two sites displayed the most complete floral coverage of all sites in the study, in excess of $90 \%$ of the surface area. Most of this coverage consists of thick moss, with subordinate willow and birch. Soil carbon and nitrogen are elevated at both sites, and carbon at Site I is the highest among the study sites, with a value of just over 3\% representing the highest individual measurement in the study. Soil $\mathrm{CO}_{2}$ flux is not similarly elevated at these sites, however. Site H, representing the oldest part of the chronosequence, demonstrates the clearest horizonation of the substrate, with a $10 \mathrm{~cm}$ silty-sandy, pale brown (5 YR 5/2) A horizon overlying a greenish-gray (5 GY 5/1), sandy-pebbly C horizon (Figure 4). Sites J, K and M all are located outside of the fence that protects the park land from grazing. Although the ages of the surfaces differ at these sites ( $\mathrm{M}$ is $1950 \mathrm{~s}, \mathrm{~K}$ is 1904 , $\mathrm{J}$ is pre-1904), the floral cover and soil carbon content for these sites is significantly reduced with respect to comparably aged sites that are not grazed. Soil nitrogen and soil $\mathrm{CO}_{2}$ flux are similar, however.

\section{Discussion}

\subsection{Carbon Storage and Soil $\mathrm{CO}_{2}$ Flux}

As shown in Figure 2, the carbon and nitrogen content of the soil increases with distance from the ice front, dem- 


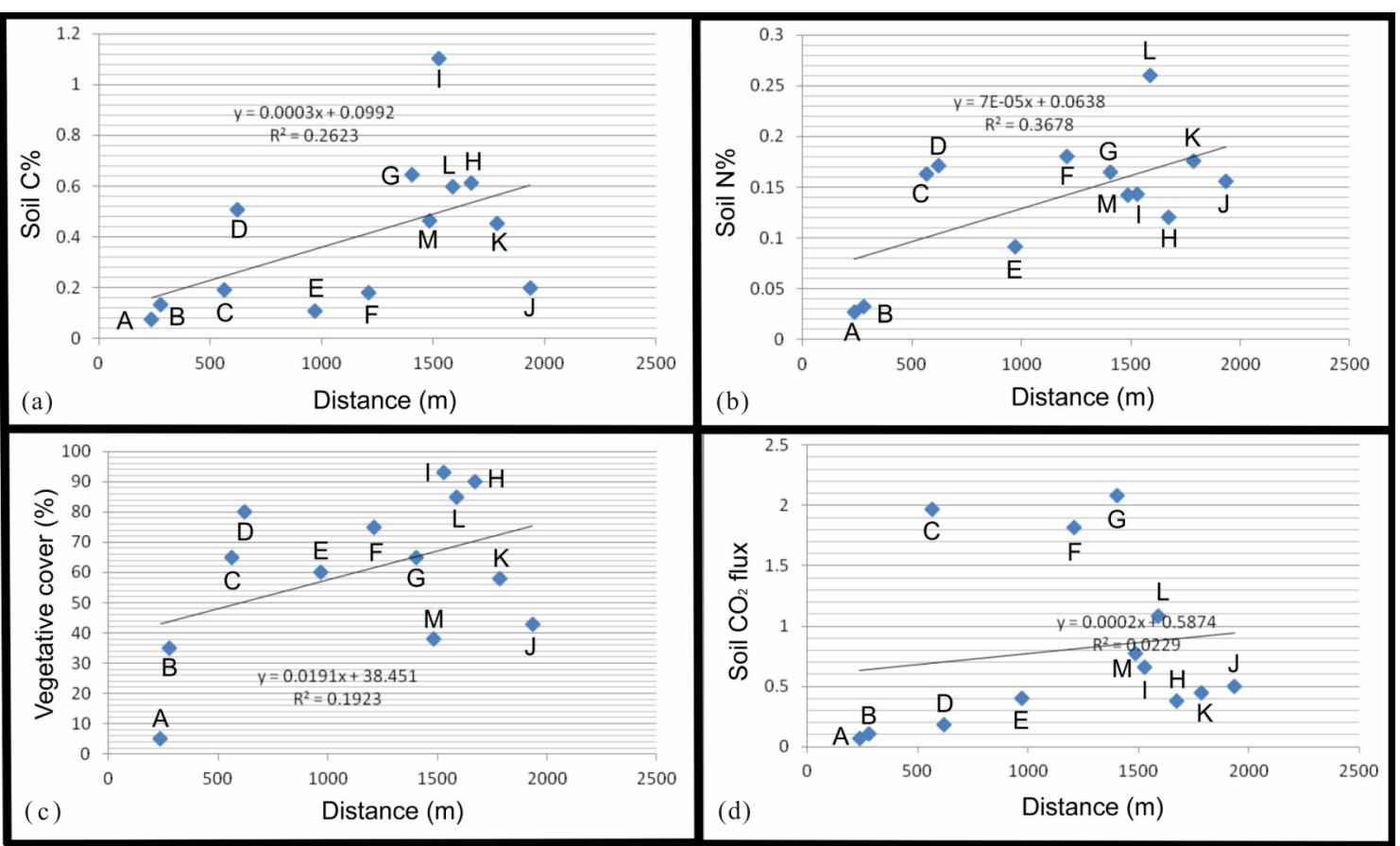

Figure 2. Measured parameters of (a) soil carbon (weight\%), (b) soil nitrogen (weight\%), (c) floral coverage (\% surface area) and (d) soil $\mathrm{CO}_{2}$ flux $\left(\mu \mathrm{mol} / \mathrm{sec} / \mathrm{m}_{2}\right)$ plotted against distance from the ice front. Letters reference sample locations from Figure 1 .
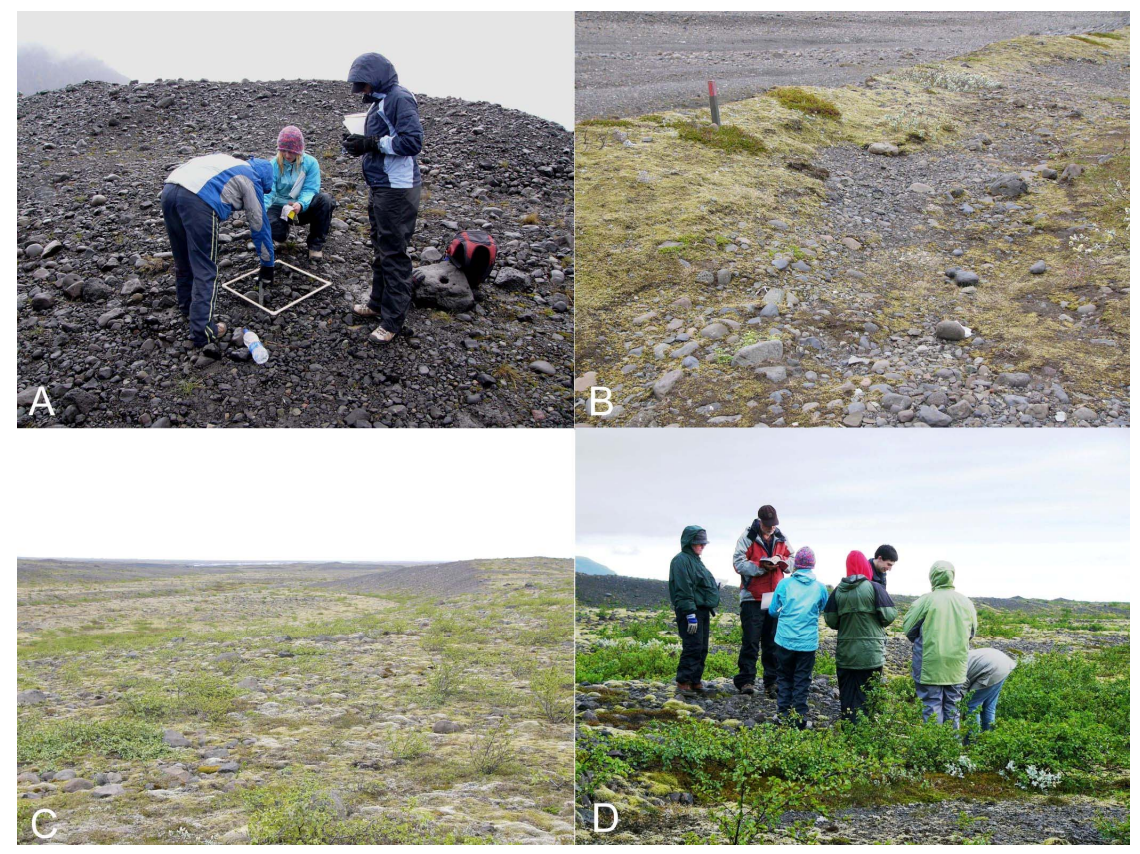

Figure 3. Sample sites on the Skaftafellsjökull chronosequence. (A) Site A is located on an ice contact till surface inclined toward the glacier. The vegetation consists solely of scattered tufts of red fescue. (B) Site B is near Site A, but behind an ice contact ridge with aspect away from the glacier. The wood stake is in a patch of crowberry. (C) Site $M$ is situated between the two ridges formed by re-advance in the early 1950s. The surface is vegetated by moss and low patches of birch. (D) Site $I$ is located on a low boulder ridge formed in 1904. Most of the shrubbery consists of birch, with a small tuft of willow.

onstrating clearly that elemental carbon and nitrogen storage on the chronosequence are at least in part a function of time. The rate of increase appears as roughly a linear function. Thus, a carbon content of $\sim 1 \%$, as at Site I (the maximum site value), where the surface is approximately 100 years old, equates to a mass of ele- 
mental carbon of $2.4 \mathrm{~kg} / \mathrm{m}^{2}$, or $2.4 \times 10^{4} \mathrm{~kg} / \mathrm{ha}$, assuming a uniform carbon concentration through a $10 \mathrm{~cm}$ solum in a soil with a mean dry density of $2.4 \mathrm{~g} / \mathrm{cm}^{3}$. Across the chronosequence, therefore, elemental carbon is sequestered in the subsurface at a rate of c. $240 \mathrm{~kg} / \mathrm{ha} / \mathrm{yr}$. The ratio of carbon to nitrogen in these soils is extremely variable, but averages about 3 . Thus, the rate of nitrogen storage is roughly one-third that of carbon. These rates accord well with those from similar studies of chronosequences in the Swiss Alps [13].

The relationship between soil $\mathrm{CO}_{2}$ flux and distance is not nearly so clear. Soil $\mathrm{CO}_{2}$ is generated primarily by root respiration and aerobic decomposition of soil organic matter. Both factors vary directly with temperature, and the lower soil temperatures in proximity to the ice will have an inhibiting effect, particularly on rates of decomposition. Root respiration will be a greater source of soil $\mathrm{CO}_{2}$ in the presence of large vascular plants.

Thus, surfaces dominated by bryophytes are likely to produce a lower $\mathrm{CO}_{2}$ flux than those vegetated surfaces with a more diverse plant assemblage. For example, sites $\mathrm{H}$ and $\mathrm{I}$ have the highest values of floral coverage, but relatively low soil $\mathrm{CO}_{2}$ flux rates, likely due to the fact that most of the surface is covered by mosses.

\subsection{Soil Formation}

Multiple studies have documented the dominance of physical processes in the initial stages of soil formation on glacial forelands. For example, Romans and others [14] described initial formation of a subsurface silty layer in the Breiðamerkurjökull chronosequence within a several years of exposure, and development of a weak silt-droplet fabric within thirty years. Similarly, Frenot and others [15] determined, through study of Antarctic proglacial chronosequences, that mechanical translocation, and mechanical processes in general, is much more important than biological modification of the soil in the initial stages of development. These findings mirrored those of Matthews [7]. Furthermore, Arnalds [16] found that plant succession is intimately related to physical substrate modification. Pioneer species are characterized by very shallow root systems that permit them to colonize the unmodified substrate. Modification of the substrate by cryogenesis decreases over time with the development of surface lag, and eolian processes continue in importance through formation of silt caps. Deeper-rooted plant species colonize only following stabilization of the surface (ending cryogenesis) and deeper translocation of the nutrient-bearing and water-retaining silty layer.

The primary difference in the parent material at our different sample sites is in particle size. The glacial foreland deposits are proximal to the glacial front, generally within $1.5 \mathrm{~km}$ of the current ice position, and thus are

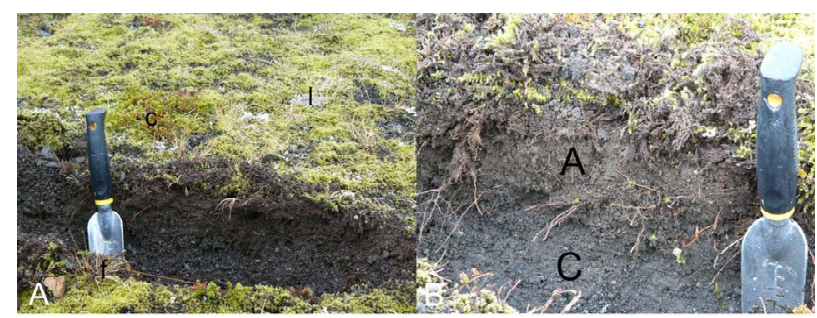

Figure 4. Soil profile at Site $\mathbf{H}$ (pre-1904). (A) The surface is covered mainly by a mat of moss, with secondary red fescue (f), crowberry (c) and foliose lichen (I). (B) Detail of (A) illustrates organic enrichment of silty A Horizon over $C$ Horizon.

particularly coarse-grained. Our preliminary investigations show that the ice-contact deposits (moraines) are largely matrix to clast-supported gravels and boulder deposits. The proximal outwash deposits are more variable, ranging from gravelly clast-supported to matrix-supported gravelly sands. Distal outwash deposits (beyond the foreland) are uniformly matrix-supported gravelly sands. In the course of our investigation, we observed no clear evidence of the separation of distinct soil horizons until we examined the oldest surfaces on the outwash plain. Here we found a distinct A Horizon, in which the color demonstrates organic enrichment, and the grain size indicates mechanical translocation of fine-grained sediment, undoubtedly of eolian origin.

Almost all soils in Iceland are derived from volcanic materials [17] and thus may be related to the soil order Andisols. In addition to tephra, these may form on glacial tills, glacio-fluvial and glacio-lacustrine deposits, and igneous rock surfaces [18]. The sample sites are located on either glacial forelands or glacial outwash plains. Thus the parent material for both sets of sample sites consists of glacial debris, deposited either as outwash or as icecontact deposits (moraines), and thus can be related to the Selsund pedon of Arnalds and Kimble [19]. All of the parent material is derived ultimately from volcanic activity, which is primarily basaltic. There is no significant difference in parent material composition between sample sites. Hence all soils in this study can be regarded as andic, either cryic andisols (or Cryands), primarily on the moraines, or andic cryofluvents on the outwash deposits [20].

\subsection{Floral Cover}

The development of the floral cover is controlled by substrate, as described above, and also aspect (slope orientation), particularly in proximity to the ice front, where the influence of katabatic winds is strongest. At Sites A and $\mathrm{B}$, for example, difference in floral cover relates primarily to aspect toward the ice at A and away from the ice at B. Similarly, Site E is located on an exposed terrace on an older surface than Site D, but has lower floral cover- 
age. Human intervention is also a factor in controlling vegetation. A portion of the surface in the park boundaries at Skaftafell has been protected from grazing since the late 1970s. The decreased floral coverage at sites J, K and $\mathrm{M}$ demonstrates the significance of the effect of grazing on the plant cover.

\section{Conclusion}

Measurements of the extent of vegetative cover, soil carbon and nitrogen content and soil $\mathrm{CO}_{2}$ flux on the chronosequence formed by the twentieth century retreat of the Skaftafellsjölull demonstrate that all four parameters increase in value approximately as a function of distance from the current ice front, which serves as a proxy for time. In addition to distance (time) from the ice, aspect is an important control on floral cover of the surface through shelter, or lack thereof, from katabatic winds. Additionally, the type of vegetation is a control on soil $\mathrm{CO}_{2}$ flux as surfaces dominated entirely by bryophytes undergo lower rates of root respiration than do areas dominated by vascular plants. Well-developed soils, with clearly differentiated $\mathrm{A}$ and $\mathrm{C}$ horizons form through organic carbon accumulation and translocation of fine-grained sediment on the oldest surfaces studied.

\section{Acknowledgements}

Dr. Guðrun Gisladottir, of the University of Iceland, provided encouragement and advice at the initiation of this project. We also thank Jessica Curry, Corinne Murray, Marcia Ruwe and Ben Thivierge for assistance in the field and laboratory. Finally, we thank the management of Vatnajökull National Park for granting access for this study.

\section{REFERENCES}

[1] P. Bousquet, P. Peylin, P. Ciais, C. Le Quere, P. Friedlingstein and P. P. Tansa, "Regional Changes in Carbon Dioxide Fluxes of Land and Oceans Since 1980," Science, Vol. 290, 2000, pp. 1342-1346. doi:10.1126/science.290.5495.1342

[2] L. R. Kump, J. F. Kasting and R. G. Crane, "The Earth System," 2nd Edition, Pearson-Prentice Hall, New York, 2004.

[3] Food and Agriculture Organization of the United Nations, "State of the World's Forests," 2001. http://www.fao.org/docrep/003/y0900e/y0900e00.htm

[4] B. B. Stephens, K. R. Gurney, P. P. Tans, C. Sweeney, W. Peters, L. Bruhwiler, P. Ciais, M. Ramonet, P. Bousquet, T. Nakazawa, S. Aoki, T. Machida, G. Inoue, N. Vinnichenko, J. Lloyd, A. A. Jordan, M. Heimann, O. Shibistova, R. L. Langenfelds, L. P. Steele, R. J. Francey and A. S. Denning, "Weak Northern and Strong Tropical Land Carbon Uptake From Vertical Profiles of Atmospheric $\mathrm{CO}_{2}$," Science, Vol. 316, No. 5832, 2007, pp. 1732-1735.

\section{doi:10.1126/science. 1137004}

[5] T. V. Callaghan, S. Jonasson, H. Nichols, R. B. Hetwood and P. A. Wookey, "Arctic Terrestrial Ecosystems and Environmental Change," Philosophical Transactions in the Physical Sciences: Engineering, Vol. 352, No. 1699, 1995, pp. 259-276. doi:10.1098/rsta.1995.0069

[6] A. C. Messer, "Regional Variations in Rates of Pedogenesis and the Influence of Climatic Factors on Moraine Chronosequences, Southern Norway," Arctic and Alpine Research, Vol. 20, No. 1, 1988, pp. 31-39. doi: $10.2307 / 1551696$

[7] J. A. Matthews, "The Ecology of Recently Deglaciated Terrain: A Geoecological Approach to Glacier Forelands and Primary Succession," Cambridge University Press, New York, 1992.

[8] P. D. Crittendon, "Nitrogen Fixation by Lichens on Glacial Drift in Iceland," New Physiologist, Vol. 74, No. 1, 1975, pp. 41-49. doi:10.1111/j.1469-8137.1975.tb01337.x

[9] I. D. Hodkinson, S. J. Coulson and N. R. Webb, "Community Assembly along Proglacial Chronosequences in the High Arctic: Vegetation and Soil Development in North-West Svalbard," Journal of Ecology, Vol. 91, No. 4, 2003, pp. 651-663. doi:10.1046/j.1365-2745.2003.00786.x

[10] O. Sigurðsson, “Glacier Variations in Iceland 1930-1995," Jökull, Vol. 45, 1998, pp. 3-26.

[11] W. J. Vreeken, "Principle Kinds of Chronosequences and Their Significance in Soil History," Journal of Soil Science, Vol. 26, No. 4, 1975, pp. 378-394. doi:10.1111/j.1365-2389.1975.tb01962.x

[12] R. J. Huggett, "Soil Chronosequences, Soil Development, and Soil Evolution: A Critical Review," Catena, Vol. 32, No. 3, 1998, pp. 155-172. doi:10.1016/S0341-8162(98)00053-8

[13] F. Conen, M. V. Yakutin, T. Zumbrunn and J. Leifeld, "Organic Carbon and Microbial Biomass in Two Soil Development Chronosequences Following Glacial Retreat," European Journal of Soil Science, Vol. 58, No. 3, 2007, pp. 758-762. doi:10.1111/j.1365-2389.2006.00864.x

[14] J. C. C. Romans, L. Robertson and D. L. Dent, "The Micromorphology of Young Soils from South-East Iceland," Geografiska Annaler: Series A, Physical Geography, Vol. 62, No. 1-2, 1980, pp. 93-103. doi:10.2307/520456

[15] Y. Frenot, B. V. Vliet-Lanoe and J.-C. Gloaguen, "Particle Translocation and Initial Soil Development on a Glacier Foreland, Kerguelen Islands, Subantarctic," Arctic and Alpine Reearch, Vol. 27, No. 2, 1995, pp. 107-115. doi:10.2307/1551892

[16] Y. Frenot, J. C. Gloaguen, M. Cannavacciuolo and A. Bellido, "Primary Succession on Glacial Forelands in the Subarctic Kerguelen Islands," Journal of Vegetative Science, Vol. 9, No. 1, 1998, pp. 75-84. doi: $10.2307 / 3237225$

[17] O. Arnalds, "Volcanic Soils of Iceland," Catena, Vol. 56, No. 1, 2004, pp. 3-20. doi:10.1016/j.catena.2003.10.002

[18] O. Arnalds, C. T. Hallmark and L. P. Wilding, "Andisols 
from Four Different Regions of Iceland," Soil Science Society of America Journal, Vol. 59, No. 1, 1995, pp. 161169. doi:10.2136/sssaj1995.03615995005900010025x

[19] O. Arnalds and J. Kimble, "Andisols of Deserts in Iceland," Soil Science Society of America Journal, Vol. 65,
No. 6, 2001, pp. 1778-1786. doi:10.2136/sssaj2001.1778

[20] A. Arnalds, "Carbon Sequestration and the Restoration of Land Health," Climatic Change, Vol. 65, No. 3, 2004, pp 333-346. doi:10.1023/B:CLIM.0000038204.60219.0a 